\title{
Processing Presupposed Content *
}

\author{
Florian Schwarz \\ University of Massachusetts at Amherst \\ Draft (currently under revision - comments welcome!)
}

February 2006

\begin{abstract}
This paper presents two experimental studies investigating the processing of presupposed content. Both studies employ the German additive particle auch (too). In the first study, participants were given a questionnaire containing bi-clausal, ambiguous sentences with 'auch' in the second clause. The presupposition introduced by auch was only satisfied on one of the two readings of the sentence, and this reading corresponded to a syntactically dispreferred parse of the sentence. The prospect of having the auch-presupposition satisfied made participants choose this syntactically dispreferred reading more frequently than in a control condition. The second study used the selfpaced-reading paradigm and compared the reading times on clauses containing auch, which differed in whether the presupposition of auch was satisfied or not. Participants read the clause more slowly when the presupposition was not satisfied. It is argued that the two studies show that presuppositions play an important role in online sentence comprehension and affect the choice of syntactic analysis. Some theoretical implications of these findings for semantic theory and dynamic accounts of presuppositions as well as for theories of semantic processing are discussed.
\end{abstract}

*An earlier version of this paper will appear in the proceedings of Sinn und Bedeutung 10 


\section{Introduction}

The study of presuppositions has been an important topic in both the philosophy of language and in linguistic semantics and pragmatics, but only more recently has it become a topic investigated with psycholinguistic methods. However, a lot can be gained from such investigations, both with respect to theoretical issues in presupposition theory as well as with respect to our understanding of semantic processing. In the following, I present two experimental studies focusing on the German additive particle auch (too). I argue that the results from these studies indicate that presuppositions play an important role early on in sentence comprehension processes. This, together with seeing other relevant studies in the processing literature from the viewpoint of semantic theory, opens up the possibility of testing theoretical claims with psycholinguistic methods. Assuming that the parser makes use of the interpretative system supplied by the grammar, the results presented here suggest that something like contextual updates (in the sense of update semantics) is carried out below the sentence level in actual processing, namely at the level of DPs. This, in turn, requires that our theory of semantic interpretation in context allows for updates at such a lower level. In addition to these theoretical conclusions, some implications for a theory of semantic processing are also discussed.

The paper is organized as follows. In the following section, I provide some background on the issues relevant to the experiments, including my theoretical assumptions about presuppositions and a few remarks about existing work on semantic processing. Section 3 presents the two experimental studies that 
were carried out. Section 4 discusses implications of the experimental results for presupposition theory and some perspectives on future research. Furthermore, some brief considerations about implications for theories of semantic processing are presented. Section 5 concludes the paper.

\section{Background}

One might start out the enterprise of investigating presuppositions in processing by wondering whether they matter at all in online sentence comprehension. After all, they are most commonly thought of as crucially relating to the context, and in the experimental settings typically used in psycholinguistic work, there is no realistic context. So it is at least possible that participants in experiments more or less ignore such context related information, especially if considerations relating to presuppositions are part of very late pragmatic processes in sentence comprehension that are more like conscious reasoning. If, on the other hand, the processor automatically made use of presupposed content, we would expect that participants would not be able to ignore it. In this case, the question becomes in what ways presuppositions can affect the parsing of incoming strings of linguistic expressions, and how quickly their content is accessible to the parser. Furthermore, we would want to know whether presuppositions interact with other factors known to be relevant in parsing, and if so in what ways. In order to address these issues in more detail, I will outline my theoretical assumptions and some of the previous findings on pragmatic processing.

From a theoretical viewpoint, we are, of course, especially interested in 
what implications experimental results might have for semantic and pragmatic theory. In connection with this it is interesting to note that most of the theoretical frameworks for the analysis of presuppositions share a procedural view of some sort which determines how presupposed content is integrated with the contextual information (although they don't make any explicit claims about actual processing). For concreteness, I will frame the discussion in this paper in terms of Heimian update semantics (Heim 1982, Heim 1983a, Heim 1983b). This is not to say that the results presented here could not be framed in other presupposition theories. In particular, they might just as well be viewed in terms of Discourse Representation Theory (Kamp 1981, Kamp and Reyle 1993, van der Sandt 1992, Geurts 1999), which shares most of the features relevant for our purposes with update semantics. ${ }^{1}$

In what is often called the Stalnaker-Karttunen-Heim tradition of presupposition theory, presuppositions are assumed to have two crucial properties: first, they are something that is taken for granted by the discourse participants. Secondly, presupposed content behaves differently from asserted content in most embedded contexts. This is at the heart of what is usually referred to as the projection problem (for an overview, see von Fintel 2004, Beaver 1997). In update semantics, which can be viewed as a formal implementation of the accounts for presuppositional phenomena by Stalnaker and Karttunen (Stalnaker 1973, Stalnaker 1974, Karttunen 1973, Karttunen 1974), the aspect of being taken for granted is modeled by the common ground, which is the set of worlds in which all of the beliefs that

\footnotetext{
${ }^{1}$ One point where update semantics and DRT potentially diverge is briefly discussed in section 4.1
} 
the discourse participants knowingly share are true. A sentence can only be felicitously uttered when the presuppositions that come with uttering the sentence are entailed by the common ground. The behavior of presuppositions in embedded contexts is accounted for by the way that the common ground is updated when a new utterance is made in the discourse. Under certain circumstances, presupposition failure can be remedied by a process of accommodation (Lewis 1979), in which the common ground is adjusted in such a way that it does entail the presupposition at issue.

Update semantics represents the meanings of sentences as context change potentials. More concretely, sentence meanings are understood as functions from contexts to contexts (where contexts are modeled either as sets of worlds or sets of pairs of worlds and assignment functions). One of the crucial issues in this type of theory is where or when context updates take place, and this is where the procedural viewpoint becomes relevant: the issue of when the adjustments to the context are made is determined by the procedural steps that the theory assumes. Quite frequently the discussion in the literature focuses on the sentence or clause level as the locus of updates, which seems intuitively plausible. However, in the full version of Heim's system, which includes assignment functions, updates also take place at the level of noun phrases (which are viewed as denoting atomic propositions). Furthermore, in order to account for certain facts concerning the behavior of presuppositions in embedded contexts, Heim (1983a) introduces the notions of local and global accommodation. As I will discuss in some more detail below, the issue of where updates take place is crucial for semantic processing viewed from the perspective of update semantics: if the processor is to make use of 
compositional semantic information, the way in which it can be used depends on the point at which it has access to it.

Before turning to the discussion of the experiments, let me briefly review some existing work on presuppositions in processing. Most related work focuses on the presupposition of the definite article and follows the basic approach taken in the seminal study of Crain and Steedman (1985) 2 Looking at locally ambiguous sentences like the one in 1 , they show that varying the discourse context (as in 2) affects the way that the sentence is parsed.

(1) The psychologist told the wife that he was having trouble with...

a. ... her husband.

b. ... to leave her husband.

(2) a. Complement Inducing Context

A psychologist was counseling a married couple. One member of the pair was fighting with him but the other one was nice to him.

b. Relative Inducing Context

A psychologist was counseling two married couples. One of the couples was fighting with him but the other one was nice to him.

In 1a the that-clause is interpreted as the complement of 'told', while in $1 \mathrm{~b}$, it is a relative clause modifying wife. The latter reading is much harder to see due to a typical garden-path effect. The preceding contexts were varied in introducing either one or two couples, the idea being that if two couples are introduced, the definite description consisting of the noun only (the wife)

\footnotetext{
${ }^{2}$ But recent work is becoming more diverse in terms of the presupposition triggers covered. See, for example, Chambers and Juan (2005) on again and for new work on pragmatic processing more generally (Noveck and Sperber 2004).
} 
cannot refer successfully, while the complex description consisting of the noun and the following that-clause analyzed as a relative clause does have a unique referent. The sentences were judged to be ungrammatical about 50 per cent of the time in a grammaticality judgment task when the context and the sentence did not match, but they were judged to be grammatical around 75 to 90 per cent of the time when the context matched. Crucially, even the garden-path in $1 \mathrm{~b}$ was ameliorated by putting it in a matching context. This finding motivated Crain and Steedman to propose a principle of parsimony, which guides the selection between different syntactic parses in their parallel parsing architecture, so that the reading carrying the fewest unsatisfied presuppositions will be the preferred one. Similar techniques are used in more recent work by van Berkum and Colleagues (van Berkum, Brown and Hagoort 1999, van Berkum, Brown, Hagoort and Zwitserlood 2003), which shows that there are ERP-effects related to whether the definite description can refer successfully or not. These studies all focus on definite descriptions and show effects of presuppositions in connection with structural parsing issues in particular parsing architectures. The studies presented here aim to broaden the range of triggers being studied and to look at effects of presuppositions in a more direct way. The experimental techniques used here contribute a new type of evidence for presupposition theory, where many hotly debated issues involve subtle intuitions. Furthermore, an attempt is made to integrate the experimental results into the theoretical discussion, in order to contribute to a theory of semantic processing informed by linguistic semantics. 


\section{Two Experimental Studies on auch}

How should we go about testing the potential effects of presuppositions in sentence processing? One of the standard techniques in psycholinguistics is to compare a normal or unproblematic form to a somehow deviant (or temporarily deviant seeming) form. This basic idea is applied to presuppositions in the two studies below in two ways: first, participants were shown ambiguous sentences containing auch, where one reading of the sentence satisfied the presupposition introduced by auch, whereas the other did not. The task, then, was to choose a paraphrase corresponding to the participants' understanding of the sentence. The second approach was to show unambiguous sentences with auch to the participants, which varied in whether the presupposition was satisfied or not. This study employed the self-paced-reading method, and participants simply had to read the sentences region by region and answer simple questions about them.

A few remarks are in order with respect to the particular choice of presupposition trigger made here. As mentioned above, the presuppositions introduced by many triggers can easily be accommodated. It certainly is a possibility to be considered that in an experimental setting participants are willing to accommodate just about any content, since the situation they are in is obviously artificial. Just compare this situation to reading an example sentence in a linguistics article. It might very well contain, say, a definite description. As a reader, there certainly is nothing odd about reading such a sentence, even if it is completely unclear and left open whether the relevant presuppositions are satisfied or not. The danger for an experimental inquiry 
into presuppositions in processing might be that they don't play any serious role at all, at least to the extent to which they can be accommodated without a problem. There are, however, a few presupposition triggers that are wellknown to at least strongly resist accommodation (cf. Beaver and Zeevat to appear). One case in point is additive particles like too, which associates with the focus of the sentence and, roughly speaking, presupposes that there is another salient entity (or property) of the same type that has the property of the background of the sentence. If there is no such discourse entity, the utterance of the sentence will be infelicitous. This is illustrated by Kripke's famous example in 3a (from Kripke 1991):

(3) a. $\mathrm{JOHN}_{F}$ is having dinner in New York tonight too.

b. Did you know that Bill is having dinner in New York tonight?

In an out of the blue context, the sentence in $3 \mathrm{a}$ is very odd, since there is no salient individual about whom it is already known in the discourse that they are having dinner in New York tonight. And even though it is completely uncontroversial that there are many people having dinner in New York every night, this presupposition failure cannot be remedied by accommodation. The utterance of $3 \mathrm{a}$ is only felicitous when there is some individual salient in the discourse that has the relevant property, e.g. in the context of $3 \mathrm{~b}$. Even though it is more or less uncontroversial that too has this property (see, for example, the discussion in Beaver and Zeevat to appear), it is worth noting recent work by Spenader (2002), who provides solid empirical evidence that the presupposition of too is hardly ever accommodated. In a corpus study of the London-Lund corpus, she finds that too lacks an antecedent 
only four per cent of the time, whereas many other presupposition triggers (e.g. definite descriptions and factives) lack an antecedent much more often (40 and 80 per cent of the time, respectively) and are apparently easily accommodated in such situations. For our concerns, then, too (as well as its German counterpart auch) lends itself to experimental investigation, as we have more control over whether presupposition failure takes place or not, without having to worry about the possibility of accommodation.

\subsection{Questionnaire Study on auch}

\subsubsection{Methods and Materials}

The basic strategy for the experimental items for the first study was to construct bi-clausal, ambiguous sentences consisting of a relative clause and a main clause. One of the readings is preferred based on well-known syntactic parsing preferences. The other reading was the one that satisfied the presupposition of auch, which appeared in the second clause. An example is given in 4

(4) Die Frau, die das Mädchen sah, hatte auch der Mann The $\operatorname{woman}_{N / A}$ who $_{N / A}$ the $\operatorname{girl}_{N / A}$ saw had also the $\operatorname{man}_{N}$ gesehen.

seen

'The woman that (saw the girl/ the girl saw) had also been seen by the man. 3

\footnotetext{
${ }^{3} N$ and $A$ stand for nominative and accusative respectively. Here and below, the passive is only used in the English paraphrase to keep the word order similar to the German one. Note that the sentences given here as well as the ones given for the other study below are only used for illustration purposes and were not used in the actual studies. The complete experimental materials are provided in the appendix.
} 
The relative clause is ambiguous due to the case-marking. In German, there is a strong and extremely well-studied parsing preference for interpreting such clauses as having a subject-object (SO) order (Hemforth 1993, Bader and Meng 1999, Schlesewsky, Fanselow, Kliegl and Krems 2000, beim Graben, Saddy, Schlesewsky and Kurths 2000, Schlesewsky and Friederici 2003). In the main clause, the unambiguously nominative marked subject appears in final position and is preceded by auch. Assuming that auch is understood as being unstressed (a plausible assumption for function words), it associates with an expression that follows it (for a discussion of stressed versus unstressed auch, see Krifka 1999), here most naturally the subject (der Mann), which yields the presupposition that someone else had seen the woman. This presupposition is not satisfied on the syntactically preferred interpretation (SO) of the relative clause. However, the syntactically dispreferred OS-reading of the relative clause (that the girl saw the woman) does satisfy this presupposition.

The task for the participants then was to choose a paraphrase that best matched their understanding of the sentence. The paraphrases for 4 would have been The man and the girl saw the woman and The woman saw the girl and the man saw the woman. This choice between paraphrases amounted to a choice between the syntactically preferred interpretation and the interpretation on which the presupposition of auch was satisfied. As a control condition, the same sentence was used but auch was replaced by vorher (here best translated as earlier), which does not introduce any presupposition whose satisfaction depends on the interpretation of the relative clause. Two further conditions followed the same basic idea, but had the order of 
the clauses reversed, with auch appearing in the relative clause. An example is given in 5 .

(5) Die Frau sah das Mädchen, das auch den Mann gesehen The $\operatorname{woman}_{N / A}$ saw the $\operatorname{girl}_{N / A} \quad$ who $_{N / A}$ also the $\operatorname{man}_{A}$ seen hatte .

had

'The woman saw the girl that had also seen the man.' or

'The woman was seen by the girl that had also seen the man.'

In this case, the matrix clause is ambiguous, and the relative clause contains auch. Note that this time the noun phrase den Mann (the man) in the relative clause is unambiguously marked accusative, so that the clause can only mean that the girl saw the man. As above, the ambiguous clause had a syntactic parsing preference for an SO-order, whereas the dispreferred OS-order satisfied the presupposition introduced by auch (that the girl saw someone else apart from the man). A control condition was again constructed by replacing auch by vorher.

Finally, a fifth condition was included, which was identical to the previous one, except that all noun phrases were ambiguously case marked:

(6) Die Frau sah das Mädchen, das auch die Lehrerin The $\operatorname{woman}_{N / A}$ saw the $\operatorname{girl}_{N / A} \quad$ who $_{N / A}$ also the teacher $N / A$ gesehen hatte .

seen had

(i) 'The woman saw the girl that had also seen the teacher.'

(ii) 'The woman was seen by the girl that had also seen the teacher.'

(iii) 'The woman saw the girl that had also been seen by the teacher.' 
As a result, the sentence was three-way ambiguous $4^{4}$ Two of the readings satisfied the presupposition of auch (namely (ii) and (iii)), but differed in whether the matrix clause or the relative clause was interpreted as having OSorder. Therefore, the results for this condition provide a further perspective on the differences between the first two pairs of conditions.

The setup resulted in a 2 X 2 design (plus the fifth condition, which was treated separately), with the presence or absence of auch as the first factor and clause order as the second factor. For the questionnaire, 30 sentences were constructed with versions for each of the five conditions above. Five versions of the questionnaire were created, varying sentences across conditions, so that each list contained 6 sentences per condition, resulting in a counterbalanced design. The questionnaire was created in HTML and made available online. The sentences were followed by disambiguated paraphrases and participants were asked to choose the paraphrase that matched their understanding of the sentence or their preferred interpretation of the sentence if more than one reading was possible. In addition to the experimental items, there were 3 items similar to the experimental ones, but preceded by a short text. Also, there were 20 unrelated filler items. Altogether, 90 native speakers of German completed the questionnaire.

\subsubsection{Results}

The results were analyzed with the percentage of the type of paraphrase chosen as the dependent variable, where the paraphrases corresponded to

\footnotetext{
${ }^{4}$ In principle, there even is a fourth reading on which both clauses are interpreted as having OS-order. But since that reading does not satisfy the auch-presupposition, it is unlikely that this reading will come to mind.
} 
Figure 1: Percentage of OS-paraphrases per condition

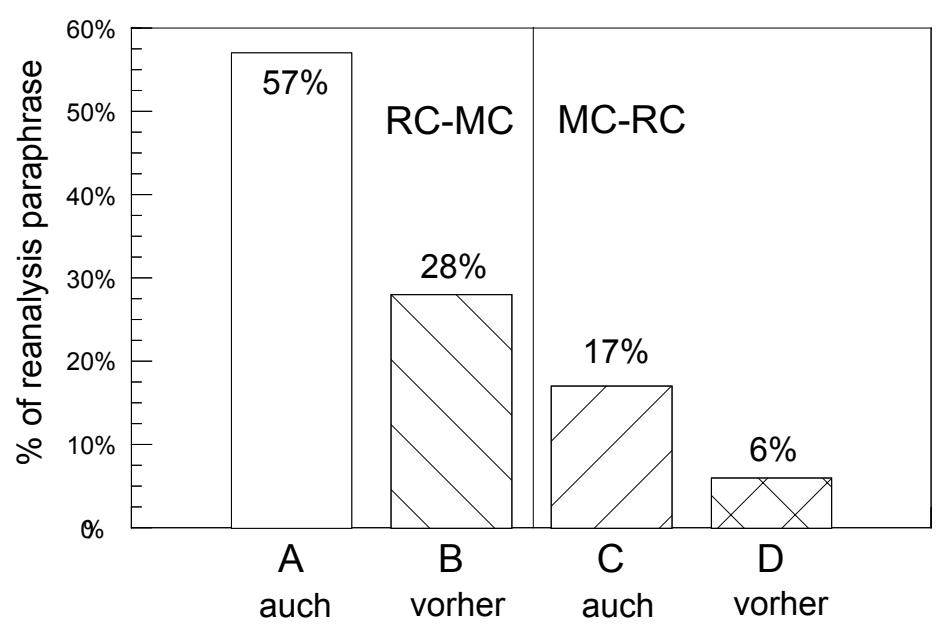

either the SO-interpretation or the OS-interpretation. The mean percentage of how often the OS-paraphrase was chosen is shown in Figure 1 for each condition.

The OS-interpretation was chosen more frequently in the auch-conditions (A and $\mathrm{C}$ ) than in the corresponding control conditions with vorher (B and D). It was also chosen more frequently in general for the relative clause before matrix clause order (RC-MC) than in the matrix clause before relative clause order (MC-RC). A 2 x 2 ANOVA (auch vs. vorher and RC-MC vs. MC-RC) was performed. There was a main effect of auch $\left(F_{1}(1,89)=\right.$ $\left.112.3, p<.001, F_{2}(1,29)=277.2, p<.001\right)$ and a main effect of clause type $\left(F_{1}(1,89)=183.3, p<.001, F_{2}(1,29)=92.1, p<.001\right)$. There also was an interaction between the two factors $\left(F_{1}(1,89)=30.7, p<.001, F_{2}(1,29)=\right.$ $37.2, p<.001)$. Two-tailed t-tests were carried out to test for simple effects 
of auch for the two types of clause orders. Both effects were significant $\left(\right.$ condition A vs. B: $t_{1}(89)=10.3, p<.001, t_{2}(29)=13.2, p<.001$, condition $\mathrm{C}$ vs. $\left.\mathrm{D}: t_{1}(89)=5.4, p<.001, t_{2}(29)=7.3, p<.001\right)$. This shows that the differences between the auch and vorher conditions are significant for each of the clause orders. In the three-way ambiguous fifth condition, the paraphrase corresponding to the OS-interpretation of the relative clause was chosen 43 per cent of the time and the paraphrase corresponding to the OSinterpretation of the matrix clause was chosen 8 per cent of the time. The syntactically preferred SO-interpretation of both clauses was chosen 49 per cent of the time.

During the initial inspection of the data, the percentage of OS-interpretations seemed to be higher in the later parts of the questionnaire. To test whether there was a significant increase, a post hoc analysis with order as a factor was carried out. Since the two clause orders varied substantially in how often the OS-paraphrase was chosen, this was done separately for the two clause orders (the fifth condition was not included). The increase in the MC-RC conditions from 8 per cent in the first half to 15 percent in the second half was significant $(t(89)=2.8, p<.01)$, whereas the increase in the RC-MC conditions from 42 to 44 per cent was not $(t(89)=2.8, p=.34)$.

\subsubsection{Discussion}

The results from the questionnaire study clearly show that participants' choice of paraphrase is influenced by the presupposition introduced by auch. When it is present, as in conditions $\mathrm{A}$ and $\mathrm{C}$, the otherwise dispreferred OS-paraphrase is chosen more frequently than when it is not, presumably 
because this order yields the auch-presupposition satisfied. This effect is present and significant for both clause orders, but stronger in the RC-MC order. Altogether, the OS-paraphrase is chosen more frequently in the RC$\mathrm{MC}$ order. This, together with the interaction, indicates that the effect of the presupposition interacts with other parsing factors.

One way of describing the process that readers might go through in reading these sentences is that they first commit themselves to an SO-interpretation of the ambiguous clause and then reanalyze that clause once they see that this renders the presupposition of auch satisfied $\left.\right|^{5}$ While this reanalysis is fairly unproblematic in the case of the ambiguous relative clause, it is most likely harder and involves at least one additional confounding factor in the the matrix clause: interpreting the clause initial DP as the object requires a special interpretation (e.g. as a topic), which is not supported by anything in the context. Therefore, it is altogether harder and less likely that participants will end up with the OS-interpretation for the MC-RC order, and the effect of the presupposition is smaller in the condition with this order. An interesting further result in the statistical analysis is that there was a practice effect reflected in a significant increase in the percentage of OS-paraphrases chosen for the MC-RC order in the second half of the questionnaire. For the RC-MC order, there was only a small numerical increase that was not significant. This supports the conclusion made above that it is harder to get the OS-interpretation in the MC-RC order. Apparently, participants become more likely to choose the OS-interpretation after having been exposed

\footnotetext{
${ }^{5}$ This description assumes a non-parallel parsing architecture. I briefly discuss the relevance of the present studies to this issue of parsing architectures in section 4.2
} 
to a number of these constructions and paraphrases for the MC-RC order, whereas they start out at a fairly high level for the other clause order.

The results from the three-way ambiguous fifth condition are also important in a number of ways. First they support the point made at the end of the last paragraph, since they show that what is behind the OS-paraphrases being chosen less often in the MC-RC condition really is that the matrix clause has to be reanalyzed. In the three-way ambiguous condition, either clause could have been given the OS-interpretation in order to satisfy the auch-presupposition. But again, we find a strong asymmetry between the relative clause and the matrix clause, with 43 per cent OS-paraphrases chosen for the relative clause and only 8 per cent OS-paraphrases for the matrix clause. This asymmetry shows that the differences between the MC-RC and the RC-MC conditions are not due to parallelism, as one might be tempted to hypothesize, since the OS-interpretation of the RC-MC conditions results in both clauses having the same order, whereas the MC-RC conditions have non-parallel orders on that interpretation. Furthermore, the asymmetry helps to fend off another alternative hypothesis, namely that the higher percentage in OS-interpretations for the RC-MC order is due to the obligatory OS-interpretation of the matrix clause. But since the OS-paraphrase of the relative clause was chosen so frequently in the three-way ambiguous condition, where no such obligatory OS-interpretation was present, this explanation seems unlikely.

In sum, then, we have found that both the presupposition of auch and the type of clause that is ambiguous have a great impact on the choice of paraphrase. The interaction seen between the effect of the presupposition and 
other parsing factors related to the differences between relative clauses and matrix clauses can be taken as a first indication that issues of presupposition satisfaction are present in online processing, although we need to be cautious in drawing any firm conclusions in this regard from an off-line questionnaire study. The study reported in the next section attempts to address this issue in a more direct way.

\subsection{Self-Paced-Reading Study on auch}

\subsubsection{Methods and Materials}

The second study used the self-paced-reading method to investigate the effect of presuppositions on the time people spent reading the relevant parts of the experimental sentences. For this study, the basic strategy was to present unambiguous versions of the materials in the first study, which varied in whether the presupposition of auch was satisfied or not. Since the effect in the questionnaire was larger for the RC-MC order, sentences using this order were used for the online study. An example illustrating the setup of the experimental items is given in $7^{6}$

(7) a. Die Frau,/ die der Junge sah,/ hatte auch der Mann The $\operatorname{woman}_{N / A}$ who $_{N / A}$ the boy saw had also the man $_{N}$ gesehen.

seen

'The woman that the boy saw had also been seen by the man.'

b. Die Frau,/ die den Jungen sah,/ hatte auch der Mann The $\operatorname{woman}_{N / A} \mathrm{who}_{N / A}$ the boy $A$ saw had also the man ${ }_{N}$

\footnotetext{
${ }^{6}$ The character ' $/$ indicates the frame breaks between the parts of the sentence that were displayed at one time in the moving-windows display (this is described in more detail below).
} 
gesehen.

seen

'The woman that saw the boy had also been seen by the man.'

In the sentence in $7 \mathrm{a}$, the noun phrase in the relative clause (der Junge, the boy) is unambiguously marked nominative, which results in the clause having OS-order and meaning that the boy saw the woman. The main clause contains auch, which (again assuming that it associates with der Mann (the man)) introduces the presupposition that someone else saw the woman. Given the meaning of the relative clause, this presupposition is satisfied. In $7 \mathrm{~b}$, on the other hand, the noun phrase den Jungen (the boy) is unambiguously marked accusative, so that the clause has SO-order and can only be understood as the woman seeing the boy. The presupposition of the main clause is as in $7 \mathrm{a}$, and is therefore not satisfied by the relative clause.

As in the questionnaire study, control conditions were constructed by replacing auch with vorher. As in the first study, this resulted in a $2 \times 2$ design, again with the presence or absence of auch as the first factor and $\mathrm{SO}$ vs. OS-order as the second factor. The study included 24 sentences with versions in each of the four conditions. The sentences were counter-balanced across conditions in four lists. Participants only saw each sentence in one condition. The experiment was programmed using E-Prime software. The presentation order of the items was randomized. Sentences were presented using the moving-window technique. On the first screen, all characters were replaced by underscores. Participants had to press the space bar to see the first part of the sentence. When they pressed the space bar again, the first part was replaced by underscores, and the next part of the sentence was 
displayed. Reading times were recorded for each displayed phrase. After each sentence, a yes-no question about that sentence was presented, and participants had to push 's' to answer 'yes' and 'k' to answer 'no'. Half of the time, 'yes' was the correct answer, and half of the time 'no' was the correct answer. Both the responses and the response times were recorded. Apart from these experimental items, there were 72 items from unrelated experiments and 12 from a related experiment. Furthermore, there were 12 filler items. Subjects received instructions about the keys they had to press, and were told to only answer questions with 'yes' if this followed directly from the sentence in question. On average it took about 30 minutes to complete the experiment. 20 native speakers of German participated in the experiment.

\subsubsection{Results}

The measure of most interest was the reading times on the clause containing auch (or vorher). Their means are shown for each condition in Figure 2.

When auch was present (conditions $\mathrm{A}$ and $\mathrm{C}$ ), the reading time in the OS condition (where the presupposition of auch was satisfied) was almost two seconds faster than in the SO-condition (where the presupposition was not satisfied). When auch was replaced by vorher, the SO condition (D) had a small advantage over the OS condition (B). Interestingly, the auch-phrase was read almost 1.5 seconds faster than the vorher phrase in the OS-condition (A vs. B), but roughly one second slower in the SO-condition (C vs. D).

A 2x2 ANOVA revealed an interaction between the two factors $\left(F_{1}(1,19)=\right.$ 26.00, $\left.p<.001, F_{2}(1,23)=17.81, p<.001\right)$. In addition, there was a 
Figure 2: Reading time on final clause in ms

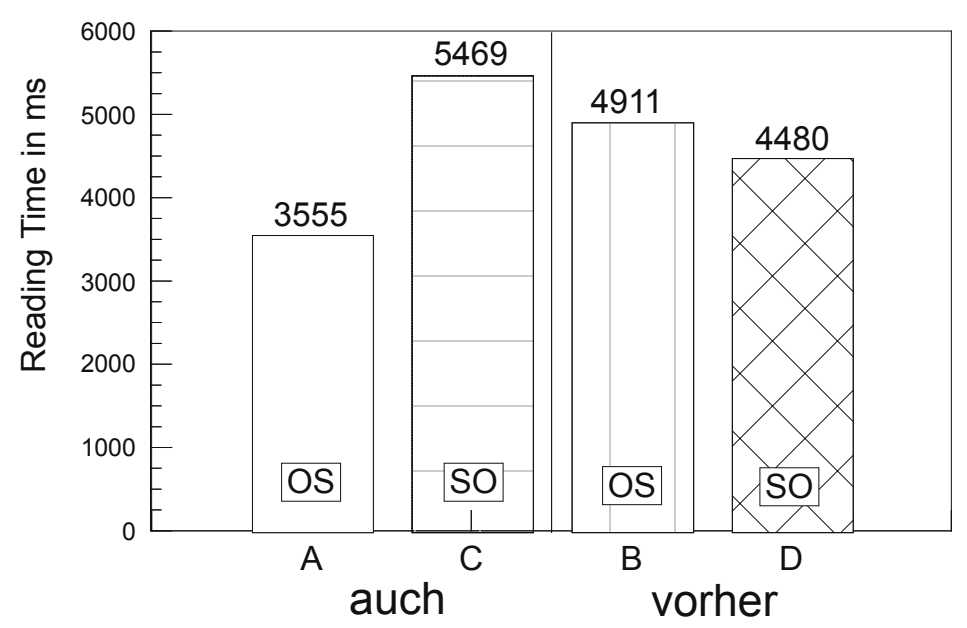

main effect of order (SO vs. OS) $\left(F_{1}(1,19)=11.58, p<.01, F 2(1,23)=\right.$ 7.88, $p=.01$ ), which was dominated by the interaction. A number of $\mathrm{t}$ tests were also carried out to test for simple effects of auch vs. vorher and OS vs. SO separately. The difference between conditions A and C was significant $\left(t_{1}(19)=-6.49, p<.001, t_{2}(23)=-4.58, p<.001\right)$, which shows that there was a simple effect of SO vs. OS-order in the auch-conditions. There also was a significant difference between A and B $\left(t_{1}(19)=-4.72, p<.001, t_{2}(23)=-5.03, p<.001\right)$, i.e. a simple effect of auch in the OS-order conditions. The difference between C and D was significant by subject and near significant by items $\left(t_{1}(19)=3.07, p<\right.$ $\left..01, t_{2}(23)=1.96, p=.06\right)$, but the difference between $\mathrm{B}$ and $\mathrm{D}$ was not significant $\left(t_{1}(19)=-1.28, p=.22, t_{2}(23)=1.25, p=.23\right)$. In terms of the statistical analysis, then, the main results are the interaction between the 
two factors and the simple effect of the order of subject and object in the relative clause. The simple effect of auch in the OS-order conditions is of interest as well, but its interpretation is less clear as it could in principle be due to a lexical effect involving auch and vorher.

Taken together, these results show that the reading times in the auch conditions were strongly influenced by SO vs. OS order (corresponding to whether the presupposition of auch is satisfied or not), while the reading times in the vorher conditions were only slightly influenced by this factor, and in the opposite direction.

As additional measures, the response times and the accuracy rates for the yes-no questions following the display of the sentence were also analyzed. There was a main effect of order, with the OS conditions having roughly an advantage of one second over the SO conditions. No other effects were significant. The accuracy rates differed only numerically, with an overall average of 78.5 per cent. The condition with the unsatisfied auch presupposition had the lowest accuracy rate (73.3 per cent).

\subsubsection{Discussion}

The results from the self-paced-reading study clearly show that the reading time on the final clause containing auch was substantially affected by whether the presupposition of auch was satisfied or not. This is not merely an effect of parallel order in the two clauses, as the effect was reversed in the vorher conditions, in which no relevant presupposition interfered.

The effect of the presupposition is rather large, at almost two seconds difference between conditions $\mathrm{A}$ and $\mathrm{C}$. It is very likely that this is due, 
at least in part, to the similarity between the conditions, and the relatively demanding task of answering the yes-no questions that followed the display of the sentence. Almost all subjects reported that it was quite difficult to keep in mind who did what to whom amongst the three people talked about in each sentence. When the presupposition did not match the content of the relative clause, it must have been even harder to keep this information straight, and this may have caused rather substantial delays when reading the final part of the sentence. In connection with this, one particularly telling comment from a participant was that she thought there were a number of spelling mistakes in the sentences, especially with the case marking on the final DP (e.g. der Mann rather than den Mann). Apparently, the expectation raised by the presupposition of auch was so strong that the mismatch was perceived as a mistake.

The strong effect on the reading time suggests that the presupposed content is evaluated online, which lends further support to the speculative conclusion above that the results from the questionnaire study are based on online effects of presuppositions. This finding is consistent with previous studies on the presuppositions of definite descriptions that were mentioned above (e.g. Crain and Steedman 1985, van Berkum et al. 2003). An additional point of interest here is that the reading times for the clause containing auch, preceded by the relative clause that satisfied the auch-presupposition (condition A), were faster than the reading times for the same clause with vorher preceded by the same relative clause (condition B). Although the possibility that this is a lexical effect of auch compared to vorher cannot be excluded at the moment, this difference could be taken to tell us something interesting 
about the role of presupposed content in natural language.7 The advantage of the auch condition might be that the presupposed content facilitates the integration of new content into the contextual representation by connecting new and old information.

The results of these studies have some interesting theoretical implications and may provide new approaches for empirical research on presuppositions. I turn to these points in the next two sections.

\section{Theoretical Implications}

Ideally, results from psycholinguistic studies can contribute to theory in two directions, which correspond to the following two questions: What do the results tell us about (the relevant part of) linguistic theory, and what can we learn from them with respect to processing theories? I will focus on the implications for semantic theory, which I turn to in the next subsection. A few brief remarks about related processing issues are made in the final part of this section.

\subsection{Implications for Semantic Theory}

Drawing theoretical conclusions from experimental results is by no means straightforward, and most likely there will always be several ways in which theoretical approaches could be made compatible with particular experimental data. I will continue to focus on a perspective from update semantics here,

\footnotetext{
${ }^{7}$ A possible remedy for this problem that was suggested by Manfred Krifka (p.c.) might be to use ebenfalls in place of auch, which is much less frequent while essentially having the same effect.
} 
again with the caveat that the results may just as well be compatible with other approaches, in particular other dynamic ones such as DRT. Toward the end of the section, I consider some evidence that might give a representational theory a small advantage. But to begin with, let us briefly consider the general question of how we can draw theoretical conclusions from experimental results such as the present ones. I take it to be the null-hypothesis that the processor makes use of the grammar when parsing linguistic input. It may have some additional principles that help to rule out many of the grammatical analyses of the structure that might in principle be possible, but it certainly should make use of the grammatical system to exclude ungrammatical analyses. If we can conclude from experimental results that the processor has access to certain information for a given structure, then we can conclude that the grammatical system must function in a way that allows it to provide this information to the parser. This is the general form of the line of argument taken below. To anticipate, I will argue that the processor evaluates the auch-clauses from the self-paced-reading materials with respect to the preceding noun phrase (including the relative clause), which means that the semantic component of the grammar must have already integrated the content of that noun phrase into the context when it encounters the auch-clause.

Now we are ready to take a closer look at the example sentences in order to understand what is going on in the processing study in slightly more refined semantic terms. The example sentence for condition A, where the presupposition of auch is satisfied by the relative clause, is repeated in 8 . 
(8) a. Die Frau,/ die der Junge sah,/ hatte auch der Mann The $\operatorname{woman}_{N / A}$ who $_{N / A}$ the boy saw had also the man $_{N}$ gesehen.

seen

'The woman that the boy saw had also been seen by the man.'

b. Presupposition of auch in general (Heim 1992) 8

$\Phi$ auch $_{i}[\alpha]_{F}$ presupposes $x_{i} \neq \alpha \& \Phi\left(x_{i}\right)$

c. Presupposition of auch in (a) (with focus on der Mann)

$\lambda x$. see $(x$, woman $)$ auch $[\text { the man }]_{F}$ presupposes

$x_{i} \neq$ the man \& $\operatorname{see}\left(x_{i}\right.$, woman $)$

As the results from the self-paced-reading study show (and as is also intuitively clear), the relative clause satisfies the presupposition characterized in $8 \mathrm{c}$. As far as the processing perspective is concerned, it appears to be the case that this is something that takes place online, since the effect shows up in the reading time on the clause that contains the presupposition trigger. This suggests the conclusion that as one is reading the part of the sentence containing auch, one is aware of the content of the relative clause (of course, that also matches our intuitive sense of what happens when we read). When we look at processing in terms of update semantics, this is rather interesting: to evaluate the presupposition of auch is to check whether the context entails it (and in the case of auch, it also involves something like checking whether there is an appropriate discourse entity having the relevant property). Since the sentence is not at all problematic in any way (neither intuitively nor in terms of the reading time results), it seems to be the case that the content of

\footnotetext{
${ }^{8}$ This formulation of the presupposition of too and auch is not without its problems, either, of course. For a more recent proposal within DRT, see van der Sandt and Geurts (2001)
} 
the relative clause is already part of the context by the time the final part of the sentence, which contains the presupposition trigger auch, is semantically processed. In other words, it looks as if the context has been updated with the sentence initial DP, including the relative clause, by the time the rest of the matrix clause is interpreted and integrated into the context.

As discussed above, it is plausible to assume that the processor makes use of the grammatical system, which allows us to draw conclusions about the latter based on findings about the former. If we think of context updates as only taking place on the level of a sentence or a full clause, we cannot explain how the initial DP can satisfy the presupposition: If we tried to apply the context change potential of the entire sentence to the neutral context, the update would fail, since the presupposition of auch is not satisfied in the initial context (and no repair would work, since the presupposition of auch cannot be accommodated). However, as I already mentioned in section 2 , in the full version of update semantics of (Heim 1983b) contexts consist of sets of pairs of worlds and assignment functions and noun phrases denote atomic propositions (and hence have complete context change potentials of their own). The meaning of definite and indefinite noun phrases is as in 9 , with the difference between definite and indefinite ones being captured with the Novelty Condition in $9 \mathrm{~b}$ :

(9) a. Let c be a context (here a set of assignment functions) and let $\mathrm{p}$ be an atomic formula, then, if defined:

$$
c+p=\left\{g: \operatorname{DOM}(g)=\bigcup \operatorname{Dom}(f) \text { s.t. } f \in c \cup\left\{i: x_{i} \text { occurs in } p\right\}\right.
$$

\footnotetext{
${ }^{9}$ For simplicity, I restrict the formal representation of contexts to sets of assignment functions
} 
$\& g$ is an extension of one of the functions in $c \& g$ verifies $p\}$

b. The Novelty/Familiarity Condition

$\mathrm{c}+\mathrm{p}$ is only defined if for every $N P_{i}$ that $\mathrm{p}$ contains, if $N P_{i}$ is definite, then $x_{i} \in \operatorname{Dom}(c)$, and if $N P_{i}$ is indefinite, then $x_{i} \notin \operatorname{Dom}(c)$.

With denotations such as these, the progression of updates for the sentences of condition A can proceed without a problem. First, the initial noun phrase is interpreted and its presupposition is evaluated with respect to the input context. It is not satisfied, but can be accommodated without a problem. Next, the rest of the matrix clause is interpreted, and the presupposition of auch is evaluated with respect to the local context. In this context it is satisfied, and the update can proceed smoothly. These steps are sketched in semi-formal terms in 10 :

(10) p: The woman $\mathrm{x}$ that the boy saw, $\mathrm{q}$ : $\mathrm{x}$ was also seen by the man

a. $c+p$ defined only if there is a unique woman that the boy saw

b. after accommodation:

$\mathrm{c}+\mathrm{p}=\{\mathrm{g}: \mathrm{g}$ verifies $\operatorname{woman}(\mathrm{x}) \& \operatorname{boy}(\mathrm{y}) \& \operatorname{see}(\mathrm{y})(\mathrm{x})\}=\mathrm{c}^{\prime}$

c. c' $+\mathrm{q}$ defined only if there is a $\mathrm{z} \neq$ the man in c' \& $\operatorname{see}(\mathrm{z})(\mathrm{x})$ defined, since the boy saw the woman, hence $\mathrm{c}^{\prime}+\mathrm{q}=\{\mathrm{g}: \mathrm{g}$ verifies $\operatorname{woman}(\mathrm{x}) \& \operatorname{boy}(\mathrm{y}) \& \operatorname{see}(\mathrm{y})(\mathrm{x}) \& \operatorname{man}(\mathrm{z})$ $\& \operatorname{see}(\mathrm{z})(\mathrm{x})\}$

This contrasts with condition $\mathrm{C}$, where the order in the relative clause has been switched around, so that even after the initial DP has become part of the context by the time the rest of the matrix clause is interpreted, the pre- 
supposition of auch is not satisfied, and there is no chance to accommodate it, since the presupposition of auch strongly resists accommodation. This problem is immediately present in processing, as reflected in the very slow reading times in that condition.

The more general picture that is evolving from this discussion is that in processing, the context is updated as soon as possible. Since noun phrases have context change potentials of their own, the processor can update the context as soon as it has been given a noun phrase. Further support for updates on this level comes from examples such as the following, where the presupposition of too is satisfied by a noun phrase which doesn't have any phrasal sub-part as in the relative clause cases considered above: ${ }^{10}$

(11) a. One of my professors works as a consultant too.

b. Critics of science use it, too.

Apparently, the noun professor suffices to satisfy the presupposition that the relevant individual works as something else than a consultant. And the (admittedly slightly playful) example in $11 \mathrm{~b}$ can be understood with focus on critics, which introduces the presupposition that other people use science. The occurrence of science seems to make it salient enough that there are scientists who do science, so that the presupposition is satisfied. In addition to the level of the noun phrase, updates can, of course, also occur at the level of the full clause (or any propositional level, for that matter). ${ }^{11}$ While

\footnotetext{
${ }^{10}$ The example in $11 \mathrm{~b}$ was a headline in the Valley Advocate on December 1st, 2005. Kai von Fintel (p.c.) suggests that this is to be understood with focus on use, with critics as the antecedent for too. While agreeing that that is a possible reading, I and several other people I have consulted find the reading discussed in the text below at least as plausible.

${ }^{11}$ Quick updates that take place whenever a propositional unit has been parsed might be
} 
further work has to determine whether this picture of semantic processing can be maintained in the long run, it seems like a clear and straightforward possibility that should make easily testable predictions that can be addressed by further experimental work.

Although there is clear evidence here that the processor deals with presupposed content online, a word of caution is in order with respect to what conclusions we can draw about how the processor goes about this. The results from the self-paced reading study are not fully conclusive with respect to the issue of whether the processor employs incremental updates using Heimian atomic propositions 'on the fly', since we are looking at the reading times for the sentence final region. It is possible that the context sensitive part of interpretation (and perhaps the compositional semantic process altogether) takes place once the entire sentence has been presented (even though this seems intuitively implausible). The slow-down in the reading time on the final region certainly is consistent with that. But even if it were the case that the integration of the content of the sentence with the context takes place at the very end of the clause, the results here show that, at that point, the procedural steps it goes through must be very much like the ones sketched in 10.

Therefore the results of the experiments presented here contribute a new kind of evidence to the theoretical discussion. They show that the processor

part of the explanation for the surprising findings in (Christianson, Hollingworth, Halliwell and Ferreira 2001), where subjects are reported to answer 'yes' 60 per cent of the time to the question 'Did Anna dress the baby' after reading the sentence 'While Anna dressed the baby baby spit up on the bed.' This finding suggests that even though subjects revise their syntactic analysis of the garden-path structure, they hold on to the incorrect interpretation (that Anna dressed the baby) corresponding to the initial syntactic analysis of the first part of the sentence. 
goes about interpreting a sentence in steps very much like those assumed by dynamic semantic theories. If we continue to assume that the processor does this by using the system supplied by the grammar, working out the details of a theory of semantic processing based on something like update semantics should make further experimentally testable predictions, which can help us to broaden the empirical foundation of semantic analyses of presuppositions. One possible follow-up to the current study would remedy the problem of the critical region being the final region by breaking up the regions into smaller chunks and by adding a continuation. This could be done by employing sentences such as the following:

(12) The woman/ who saw the boy/ also saw/ the man/ yesterday/ on her way to work.

In addition to these considerations about the online study, we should also note the relevance of the findings of the questionnaire study in this respect. Assuming a model of the syntactic parser that only pursues one structural analysis at the time, we find a remarkable amount of effort put into reanalysis of the relative clause that already had been previously parsed with an SO-order, which is revised in order to satisfy the presupposition. The fact that this revision is even considered indicates that the meaning of the relative clause is already accessible to the parser at the time it encounters the presupposition. With respect to this point, representational theories such as DRT might have an advantage over non-representational approaches such as update semantics. When the parser considers the revision of the analysis of the relative clause, it must somehow see that the reversal of the syntactic 
roles of the subject and the object yields an interpretation that will just be of the right kind to satisfy the presupposition of too. This is easily imaginable if the parser has access to representations such as see( $x, y)$, but possibly problematic if all the parser can see is syntactic structure and propositions. Since there is no obvious connection or relation between the set of worlds in which $\mathrm{x}$ sees $\mathrm{y}$ and the set of worlds in which $\mathrm{y}$ sees $\mathrm{x}$, having access to the propositional meaning only does not seem to be enough to trigger reanalysis. In connection with this, it is worthwhile to note that it in general seems to be fairly easy for the processor to invert relations when there is enough evidence, as was shown in recent work by Kim and Osterhout (2005).

Needless to say, a lot of work needs to be done to relate more complex theoretical issues to processing results. One interesting question is what happens when a presupposition trigger like auch appears early on in a sentence, with the part that satisfies it following later on, as in the following sentence: ${ }^{12}$

(13) Auch die Frau, die das Kind sah, hatte der Mann Also the ${ }_{N / A}$ woman who $_{N / A}$ the ${ }_{N / A}$ child saw had the ${ }_{N}$ man gesehen.

seen

'Also the woman that the child saw was seen by the man.' or

'Also the woman that saw the child was seen by the man.'

While it is unclear to me what exactly to expect in connection with this in terms of processing results, it is intuitively clear that there is a certain element of suspense in sentences like this, with a high expectation that the presupposition of auch will be satisfied by something that is coming later on

\footnotetext{
${ }^{12}$ Thanks to Francesca Panzeri and Hans Kamp for independently bringing my attention to this question.
} 
in the sentence.

Future work will hopefully be able to address questions related to current issues in the presupposition literature more directly, for example the ever pressing issue of local and global accommodation (see Heim's work and for a recent critical position on local accommodation, van Rooy 1999). If the general approach pursued in this paper is on the right track, local accommodation becomes a very plausible mechanism from the viewpoint of processing. Another important issue, partly related to this, which has also received a lot of recent attention is the old question of whether presuppositions are at heart semantic or pragmatic (Stalnaker 1974, Simons 2001, Abusch 2005, Beaver and Krahmer 2001). The apparent automatic nature of the presence of the presupposition of auch in the processing picture might lend some support to a semantic view (at least for the presupposition of auch), but that, of course, depends on how we deal with pragmatic phenomena in processing in general. Without being able to go into the details of these issues, I hope that the present findings will inspire further exploration of these topics from a processing perspective.

\subsection{Implications for Processing Theories}

Let us now turn to some considerations about what the results reported here mean for a theory of semantic processing. At this point, we aren't anywhere close to having a realistic idea of how compositional semantic processing takes place online. One central question, of course, is at what point the processor actually goes through steps of semantic composition and at what 
point the content of the currently processed linguistic unit is integrated with the information present in the context (which crucially should involve the evaluation of presuppositions with respect to that context). Modulo the caveat about the possible conclusions of the present studies concerning the issue of whether the processor goes through the steps of updating the context 'on the fly' or whether it does so at a later point, a viable hypothesis can be constructed from what has been said here: Apart from the level of full clauses, where we obviously are dealing with propositional units, updates also take place at the level of noun phrases. This amounts to a straightforward extension of update semantics to the theory of processing. Whether or not this can be upheld, it is the simplest assumption that the processor makes use of the system supplied by the grammar, and it has the advantage of making predictions that should, at least in principle, be experimentally testable. Hopefully, this will also enable us to investigate further theoretical issues in presupposition theory in new ways.

Apart from these issues related immediately to semantic processing, the studies might also contribute to more general architectural questions in processing theory, although I can only make some brief remarks about these here. Let me just mention one particularly interesting point, namely that the results from the questionnaire study are most likely problematic for a simple version of a parallel parsing architecture along the lines of the one proposed by Crain and Steedman (1985). The idea in this work is that when the processor deals with an ambiguous structure, it considers all possible structures at the same time, with some structures being filtered out by certain principles. One central principle that they assume to account for the data 
mentioned above in 1 is the principle of parsimony, which only keeps those interpretations that have the fewest presuppositions violated. One of the more intriguing aspects of the questionnaire study discussed here was the interaction of how often subjects would choose the syntactically dispreferred structure (to have the presupposition of auch satisfied) with the order the clauses appeared in (which affected whether the matrix clause or the relative clause was ambiguous). If people were considering both interpretations of the ambiguous clauses at the same time, and then would choose one of them based on which one has the fewest presupposition violations, we would expect that they would choose the reading on which the auch-presupposition is violated more often (in the MC-RC condition with auch, they chose it only 17 per cent of the time, and even in the RC-MC order condition, they chose it only 57 per cent of the time). Furthermore, we would not expect that the two clause orders would differ so drastically in this respect.

\section{Conclusion}

I have argued that the results from the studies reported here suggest that the processor has access to and makes use of presupposed content in online processing and employs something like context updates at the level of noun phrases. In a sense, this means taking the 'dynamic' aspect of dynamic semantics quite literally by claiming that the linguistic processor employs dynamic updates in the process of interpreting a sentence compositionally. Bringing our theoretical frameworks and processing theories closer together in this way has the advantage of being temptingly simple. Whether or not 
this turns out to be realistic in the long run, it should enable us to come up with straightforward predictions that we can test in further work. This opens up the possibility of extending the empirical foundation for work in theoretical semantics and of addressing central issues in presupposition theory that often involve disputes about the intuitive status of presupposed content. Investigating these issues in a more direct empirical way will make an important contribution to the theoretical discussion. Once we have a better understanding of what kind of effects related to presuppositions there are in processing, we can hope to address more sophisticated questions in presupposition theory (e.g. the issue of local and global accommodation) in new ways.

\section{Author's Address}

\section{FLORIAN SCHWARZ}

Department of Linguistics

University of Massachusetts at Amherst

226 South College

150 Hicks Way

Amherst, MA 01003

florian@linguist.umass.edu 


\section{Acknowledgments}

Thanks for comments and discussion are due to Lyn Frazier, Angelika Kratzer, Chuck Clifton, John Kingston, Chris Potts, Florian Jäger, Kai von Fintel,

Kristen Syrett, Greg Carlson, Barbara Partee, Paula Menendez-Benito, Jan Anderssen, the participants of 2nd Year Seminar and Semantics Reading Group, and the audience at Sinn and Bedeutung 10. Part of this work was supported by NIH Grant HD-18708 to the University of Massachusetts.

\section{A Materials}

\section{A.1 auch-questionnaire materials}

1. a. Das Marketingteam, das die Abteilungsleiterin beraten hat, hatte The $_{N / A}$ marketing-team $\mathrm{RP}_{N / A}$ the $\mathrm{N}_{N / A}$ department-head advised has, had auch der Geschftsführer beraten. also the ${ }_{N}$ CEO advised.

'The marketing-team that the department head advised, had also been advised by the CEO.' or

'The marketing-team that advised the department-head had also been advised by the CEO.'

b. Das Marketingteam, das die Abteilungsleiterin beraten hat, hatte The $_{N / A}$ marketing-team $\mathrm{RP}_{N / A}$ the $\mathrm{N}_{N / A}$ department-head advised has, had vorher der Geschäftsführer beraten. before the ${ }_{N}$ CEO advised.

Paraphrases to choose from for (a) and (b):

i. Die Abteilungsleiterin wurde von dem Marketingteam beraten, und das the department-head was by the ${ }_{D}$ marketing-team advised and the Marketingteam von dem Geschäftsführer. marketing-team by the ${ }_{D} \mathrm{CEO}$

'The department-head was advised by the marketing-team and the marketingteam by the CEO.'

ii. Das Marketingteam wurde von der Abteilungsleiterin und vom the marketing-team was by the ${ }_{D}$ department-head and by-the Geschäftsführer beraten. CEO advised

'The marketing-team was advised by the department-head and by the CEO.' 
c. Das Marketingteam beriet die Abteilungsleiterin, die auch den The $_{N / A}$ marketing-team advised the ${ }_{N / A}$ department-head $\mathrm{RP}_{N / A}$ also, the $A$ Geschäftsführer beraten hatte.

CEO advised had.

'The marketing-team advised the department-head that also had advised the CEO.' or

'The marketing-team was advised by the department-head that also had advised the CEO.'

d. Das Marketingteam beriet die Abteilungsleiterin, die vorher den The $_{N / A}$ marketing-team advised the $\mathrm{N}_{N / A}$ department-head $\mathrm{RP}_{N / A}$ before, the ${ }_{A}$ Geschäftsführer beraten hatte.

CEO advised had.

Paraphrases to choose from for $(\mathrm{c})$ and $(\mathrm{d})$ :

i. Die Abteilungsleiterin wurde von dem Marketingteam beraten und der the department-head was by the ${ }_{D}$ marketing-team advised and the Geschäftsführer von der Abteilungsleiterin.

CEO by the ${ }_{D}$ department-head

'The department-head was advised by the marketing-team and the CEO by the department-head'

ii. Das Marketingteam und der Geschäftsführer wurden von der the marketing-team and the ${ }_{N}$ CEO were by the ${ }_{D}$ Abteilungsleiterin beraten. department-head advised

'The marketing-team and the CEO were advised by the department-head'

e. Das Marketingteam beriet die Abteilungsleiterin, die vorher The $_{N / A}$ marketing-team advised the ${ }_{N / A}$ department-head $\mathrm{RP}_{N / A}$ before, die Geschäftsführerin beraten hatte.

the $_{N / A}$ CEO advised had.

Paraphrases to choose from for (e):

i. Die Abteilungsleiterin wurde von dem Marketingteam beraten, und die the department-head was by the ${ }_{D}$ marketing-team advised and the Geschäfsführerin von der Abteilungsleiterin. CEO by the $_{D}$ department-head

'The department-head was advised by the marketing-team and the CEO by the department-head.'

ii. Die Abteilungsleiterin wurde von dem Marketingteam und von der the department-head was by the ${ }_{D}$ marketing-team und by the ${ }_{D}$ Geschäftsführerin beraten. CEO advised

'The department-head was advised by the marketing-team and by the CEO.'

iii. Das Marketingteam und die Geschäftsführerin wurden von der the marketing-team and the CEO were by the ${ }_{D}$ Abteilungsleiterin beraten. department-head advised

'The marketing-team and the CEO were advised by the department-head.' 
2. a. Die Mitarbeiterin, die die Sekretärin auswählte, hatte auch der Direktor The employee RP the secretary chose had also the director ausgewählt. chosen

b. Die Mitarbeiterin, die die Sekretärin auswählte, hatte vorher der Direktor ausgewählt.

c. Die Mitarbeiterin wählte die Sekretärin aus, die auch den Direktor ausgewählt hatte.

d. Die Mitarbeiterin wählte die Sekretärin aus, die vorher den Direktor ausgewählt hatte.

e. Die Mitarbeiterin wählte die Sekretärin aus, die auch die Direktorin ausgewählt hatte.

3. a. Die Spionin, die die Kommissarin verfolgt hat, hatte auch der KGB Mann

The spy RP the superintendent chased has had also the KGB man verfolgt. chased.

b. Die Spionin, die die Kommissarin verfolgt hat, hatte vorher der KGB Mann verfolgt.

c. Die Spionin verfolgte die Kommissarin, die auch den KGB Mann verfolgt hatte.

d. Die Spionin verfolgte die Kommissarin, die vorher den KGB Mann verfolgt hatte.

e. Die Spionin verfolgte die Kommissarin, die auch die KGBF rau verfolgt hatte.

4. a. Die Grenzbeamtin, die die Polizistin kontrollierte, hatte auch der The border-officer RP the police-officer examined had also the Staatsanwalt kontrolliert. prosecutor examined.

b. Die Grenzbeamtin, die die Polizistin kontrolliert hat, hatte vorher der Staatsanwalt kontrolliert.

c. Die Grenzbeamtin kontrollierte die Polizistin, die auch den Staatsanwalt kontrolliert hatte.

d. Die Grenzbeamtin kontrollierte die Polizistin, die vorher den Staatsanwalt kontrolliert hatte.

e. Die Grenzbeamtin kontrollierte die Polizistin, die auch die Staatsanwältin kontrolliert hatte.

5. a. Die Professorengruppe, die das Expertenteam begutachtete, hatte auch der The group-of-professors RP the expert-team reviewed had also the Universitätspräsident begutachtet. university-president reviewed.

b. Die Professorengruppe, die das Expertenteam begutachtete, hatte vorher der Universitätspräsident begutachtet.

c. Die Professorengruppe begutachtete das Expertenteam, das auch den Universitätspräsidenten begutachtet hatte.

d. Die Professorengruppe begutachtete das Expertenteam, das vorher den Universitätspräsidenten begutachtet hatte.

e. Die Professorengruppe begutachtete das Expertenteam, das auch die Universitätspräsidentin begutachtet hatte. 
6. a. Die Redakteurin, die das Projektmitglied begleitete, hatte auch der The editor RP the project-member accompanied had also the Computertechniker begleitet. computer-technician accompanied

b. Die Redakteurin, die das Projektmitglied begleitete, hatte vorher der Computertechniker begleitet.

c. Die Redakteurin begleitete das Projektmitglied, das auch den Computertechniker begleitet hatte.

d. Die Redakteurin begleitete das Projektmitglied, das vorher den Computertechniker begleitet hatte.

e. Die Redakteurin begleitete das Projektmitglied, das auch die Computertechnikerin begleitet hatte.

7. a. Das norwegische Team, das die finnische Mannschaft besiegte, hatte auch der The Norwegian team RP the Finish team defeated had also the Jemen besiegt.

Yemen defeated

b. Das norwegische Team, das die finnische Mannschaft besiegte, hatte vorher der Jemen besiegt.

c. Das norwegische Team besiegte die finnische Mannschaft, die auch den Jemen besiegt hatte.

d. Das norwegische Team besiegte die finnische Mannschaft, die vorher den Jemen besiegt hatte.

e. Das norwegische Team besiegte die finnische Mannschaft, die auch die Türkei besiegt hatte.

8. a. Die Lehrerin, die die Mutter begrüsste, hatte auch der Schulrat the teacher RP the mother welcomed had also the super-intendent begrüsst. welcomed.

b. Die Lehrerin, die die Mutter begrüsste, hatte vorher der Schulrat begrüsst.

c. Die Lehrerin begrüsste die Mutter, die auch den Schulrat begrüsst hatte.

d. Die Lehrerin begrüsste die Mutter, die vorher den Schulrat begrüsst hatte.

e. Die Lehrerin begrüsste die Mutter, die auch die Schulrätin begrüsst hatte.

9. a. Das Anwaltsbüro, das die Ärztin konsultierte, hatte auch der Professor the law-firm RP the doctor consulted had also the professor konsultiert. consulted

b. Das Anwaltsbüro, das die Ärztin konsultierte, hatte vorher der Professor konsultiert.

c. Das Anwaltsbüro konsultierte die Ärztin, die auch den Professor konsultiert hatte.

d. Das Anwaltsbüro konsultierte die Ärztin, die vorher den Professor konsultiert hatte.

e. Das Anwaltsbüro konsultierte die Ärztin, die auch die Professorin konsultiert hatte.

10. a. Die Italienerin, die die Studentin unterrichtete, hatte auch der Musiklehrer the Italian RP the student taught had also the music-teacher unterrichtet. taught 
b. Die Italienerin, die die Studentin unterrichtete, hatte vorher der Musiklehrer unterrichtet.

c. Die Studentin unterrichtete die Italienerin, die auch den Musiklehrer unterrichtet hatte.

d. Die Studentin unterrichtete die Italienerin, die vorher den Musiklehrer unterrichtet hatte.

e. Die Studentin unterrichtete die Italienerin, die auch die Musiklehrerin unterrichtet hatte.

11. a. Die Putzfrau, die die alte Dame suchte, hatte auch der kleine Junge the cleaner RP the old lady looked-for had also the small boy gesucht.

looked-for

b. Die Putzfrau, die die alte Dame suchte, hatte vorher der kleine Junge gesucht.

c. Die Putzfrau suchte die alte Dame, die auch den kleinen Jungen gesucht hatte.

d. Die Putzfrau suchte die alte Dame, die vorher den kleinen Jungen gesucht hatte.

e. Die Putzfrau suchte die alte Dame, die auch das kleine Mädchen gesucht hatte.

12. a. Das Computergenie, das die Schachspielerin beobachtete, hatte auch der the computer-genius RP the actress watched had also the

Programmierer beobachtet. programmer watched

b. Das Computergenie, das die Schachspielerin beobachtete, hatte vorher der Programmierer beobachtet.

c. Das Computergenie beobachtete die Schachspielerin, die auch den Programmierer beobachtet hatte.

d. Das Computergenie beobachtete die Schachspielerin, die vorher den Programmierer beobachtet hatte.

e. Das Computergenie beobachtete die Schachspielerin, die auch die Programmiererin beobachtet hatte.

13. a. Die Krankenschwester, die die Pflegerin überwachte, hatte auch der the nurse RP the caregiver supervised had also the

Stationsleiter überwacht.

station-chief supervised

b. Die Krankenschwester, die die Pflegerin überwachte, hatte vorher der Stationsleiter überwacht.

c. Die Krankenschwester überwachte die Pflegerin, die auch den Stationsleiter überwacht hatte.

d. Die Krankenschwester überwachte die Pflegerin, die vorher den Stationsleiter überwacht hatte.

e. Die Krankenschwester überwachte die Pflegerin, die auch die Stationsleiterin überwacht hatte.

14. a. Die Sängerin, die die Galeristin einlud, hatte auch der Kurator eingeladen. the singer RP the gallery-owner invited had also the curator invited

b. Die Sängerin, die die Galeristin einlud, hatte vorher der Kurator eingeladen.

c. Die Sängerin lud die Galeristin ein, die auch den Kurator eingeladen hatte. 
d. Die Sängerin lud die Galeristin ein, die vorher den Kurator eingeladen hatte.

e. Die Sängerin lud die Galeristin ein, die auch die Kuratorin eingeladen hatte.

15. a. Die Lektorin, die die Schriftstellerin lobte, hatte auch der Verleger gelobt. the editor RP the author praised had also the publisher praised

b. Die Lektorin, die die Schriftstellerin lobte, hatte vorher der Verleger gelobt.

c. Die Lektorin lobte die Schriftstellerin, die auch den Verleger gelobt hatte.

d. Die Lektorin lobte die Schriftstellerin, die vorher den Verleger gelobt hatte.

e. Die Lektorin lobte die Schriftstellerin, die auch die Verlegerin gelobt hatte.

16. a. Die Goldschmiedin, die die Schneiderin beauftragte, hatte auch der Gärtner the gold-smith RP the seamstress commissioned had also the gardener beauftragt. commissioned

b. Die Goldschmiedin, die die Schneiderin beauftragte, hatte vorher der Gärtner beauftragt.

c. Die Goldschmiedin beauftragte die Schneiderin, die auch den Gärtner beauftragt hatte.

d. Die Goldschmiedin beauftragte die Schneiderin, die vorher den Gärtner beauftragt hatte.

e. Die Goldschmiedin beauftragte die Schneiderin, die auch die Gärtnerin beauftragt hatte.

17. a. Die Cellistin, die die Komponistin bewunderte, hatte auch der Dirigent the cellist RP the composer admired had also the director bewundert. admired

b. Die Cellistin, die die Komponistin bewunderte, hatte früher der Dirigent bewundert.

c. Die Cellistin bewunderte die Komponistin, die auch den Dirigenten bewunderte.

d. Die Cellistin bewunderte die Komponistin, die vorher den Dirigenten bewunderte.

e. Die Cellistin bewunderte die Komponistin, die auch die Dirigentin bewundert hatte.

18. a. Die Apothekerin, die die Optikerin benachrichtigte, hatte auch der Pfarrer the pharmacist RP the optician notified had also the pastor benachrichtigt. notified

b. Die Apothekerin, die die Optikerin benachrichtigte, hatte vorher der Pfarrer benachrichtigt.

c. Die Apothekerin benachrichtigte die Optikerin, die auch den Pfarrer benachrichtigt hatte.

d. Die Apothekerin benachrichtigte die Optikerin, die vorher den Pfarrer benachrichtigt hatte.

e. Die Apothekerin benachrichtigte die Optikerin, die auch die Pfarrerin benachrichtigt hatte. 
19. a. Die Vereinigung, die das Projekt unterstützte, hatte auch der Bürgermeister the association RP the project supported had also the mayor unterstützt. supported

b. Die Vereinigung, die das Projekt unterstützte, hatte vorher der Bürgermeister unterstützt.

c. Die Vereinigung unterstützte das Projekt, das auch den Bürgermeister unterstützt hatte.

d. Die Vereinigung unterstützte das Projekt, das vorher den Bürgermeister unterstützt hatte.

e. Die Vereinigung unterstützte das Projekt, das auch die Bürgermeisterin unterstützt hatte.

20. a. Das Model, das die Fotografin kontaktierte, hatte auch der Designer the model RP the photographer contacted had also the designer kontaktiert. contacted

b. Das Model, das die Fotografin kontaktierte, hatte vorher der Designer kontaktiert.

c. Das Model kontaktierte die Fotografin, die auch den Designer kontaktiert hatte.

d. Das Model kontaktierte die Fotografin, die vorher den Designer kontaktiert hatte.

e. Das Model kontaktierte die Fotografin, die auch die Designerin kontaktiert hatte.

21. a. Die Klassenlehrerin, die das Wunderkind verabschiedete, hatte auch der the teacher RP the child-prodigy saw-off had also the Rektor verabschiedet. principal seen-off

b. Die Klassenlehrerin, die das Wunderkind verabschiedete, hatte vorher der Rektor verabschiedet.

c. Das Wunderkind verabschiedete die Direktorin, die auch den Klassenlehrer verabschiedet hatte.

d. Das Wunderkind verabschiedete die Direktorin, die vorher den Klassenlehrer verabschiedet hatte.

e. Das Wunderkind verabschiedete die Direktorin, die auch die Klassenlehrerin verabschiedet hatte.

22. a. Die Kindergärtnerin, die das kleine Mädchen getroffen hat, hatte auch der the nursery-teacher RP the little girl met has had also the Elternvereinsvorsitzende getroffen. parent-representative met

b. Die Kindergärtnerin, die das kleine Mädchen getroffen hat, hatte vorher der Elternvereinsvorsitzende getroffen.

c. Die Kindergärtnerin traf das kleine Mädchen, das auch den Elternvereinsvorsitzenden getroffen hatte.

d. Die Kindergärtnerin traf das kleine Mädchen, das vorher den Elternvereinsvorsitzenden getroffen hatte.

e. Die Kindergärtnerin traf das kleine Mädchen, das auch die Elternvereinsvorsitzende getroffen hatte. 
23. a. Die Pianistin, die die Malerin besuchte, hatte auch der Cellist besucht. the pianist RP the painter visited had also the cellist visited

b. Die Pianistin, die die Malerin besuchte, hatte vorher der Cellist besucht.

c. Die Pianistin besuchte die Malerin, die auch den Cellisten besucht hatte.

d. Die Pianistin besuchte die Malerin, die vorher den Cellisten besucht hatte.

e. Die Pianistin besuchte die Malerin, die auch die Cellistin besucht hatte.

24. a. Die Schönheitskönigin, die das Gewinnerpaar beglückwünschte, the beauty-queen RP the winner-couple congratulated

beglückwünschte auch der Showmaster.

congratulated also the host

b. Die Schönheitskönigin, die das Gewinnerpaar beglückwünschte, hatte vorher der Showmaster beglückwünscht.

c. Die Schönheitskönigin beglückwünschte das Gewinnerpaar, das auch den Showmaster beglückwünscht hatte.

d. Die Schönheitskönigin beglückwünschte das Gewinnerpaar, das vorher den Showmaster beglückwünscht hatte.

e. Die Schönheitskönigin beglückwünschte das Gewinnerpaar, das auch die Showmasterin beglückwünscht hatte.

25. a. Die Klientin, die die Maklerin überredete, hatte auch der Hausmeister the client RP the real-estate-agent convinced had also the janitor

überredet.

convinced

b. Die Klientin, die die Maklerin überredete, hatte vorher der Hausmeister überredet.

c. Die Klientin überredete die Maklerin, die auch den Hausmeister überredet hatte.

d. Die Klientin überredete die Maklerin, die vorher den Hausmeister überredet hatte.

e. Die Klientin überredete die Maklerin, die auch die Hausmeisterin überredet hatte.

26. a. Das Aufsichtsratsmitglied, das die Grafikerin überzeugte, hatte auch der the board-member RP the designer convinced had also the Kreativdirektor überzeugt. art-director convinced

b. Das Aufsichtsratsmitglied, das die Grafikerin überzeugte, hatte vorher der Kreativdirektor überzeugt.

c. Das Aufsichtsratsmitglied überzeugte die Grafikerin, die auch den Kreativdirektor überzeugt hatte.

d. Das Aufsichtsratsmitglied überzeugte die Grafikerin, die vorher den Kreativdirektor überzeugt hatte.

e. Das Aufsichtsratsmitglied überzeugte die Grafikerin, die auch die Kreativdirektorin überzeugt hatte.

27. a. Die Gastmoderatorin, die die Sopranistin ankündigte, hatte auch der the guest-host RP the soprano announced had also the Programmdirektor angekündigt. head of programming announced

b. Die Gastmoderatorin, die die Sopranistin ankündigte, hatte vorher der Programmdirektor angekündigt. 
c. Die Gastmoderatorin kündigte die Sopranistin an, die auch den Programmdirektor angekündigt hatte.

d. Die Gastmoderatorin kündigte die Sopranistin an, die vorher den Programmdirektor angekündigt hatte.

e. Die Gastmoderatorin kündigte die Sopranistin an, die auch die Programmdirektorin angekündigt hatte.

28. a. Das Touristenehepaar, das die Künstlerin fotografierte, hatte auch der the tourist-couple RP the artist photographed had also the Journalist fotografiert. journalist photographed

b. Das Touristenehepaar, das die Künstlerin fotografierte, hatte vorher der Journalist fotografiert.

c. Das Touristenehepaar fotografierte die Künstlerin, die auch den Journalisten fotografiert hatte.

d. Das Touristenehepaar fotografierte die Künstlerin, die vorher den Journalisten fotografiert hatte.

e. Das Touristenehepaar fotografierte die Künstlerin, die auch die Journalistin fotografiert hatte.

29. a. Die Besucherin, die die Dichterin erkannte, hatte auch der Gastgeber the visitor RP the poet recognised had also the host

erkannt.

recognised

b. Die Besucherin, die die Dichterin erkannte, hatte vorher der Gastgeber erkannt.

c. Die Besucherin erkannte die Dichterin, die auch den Gastgeber erkannt hatte.

d. Die Besucherin erkannte die Dichterin, die vorher den Gastgeber erkannt hatte.

e. Die Besucherin erkannte die Dichterin, die auch die Gastgeberin erkannt hatte.

30. a. Die Staatsanwältin, die die Kommission beurteilte, hatte auch der Richter the prosecutor RP the commission assessed had also the judge

beurteilt.

assessed

b. Die Staatsanwältin, die die Kommission beurteilte, hatte vorher der Richter beurteilt.

c. Die Staatsanwältin beurteilte die Kommission, die auch den Richter beurteilt hatte.

d. Die Staatsanwältin beurteilte die Kommission, die vorher den Richter beurteilt hatte.

e. Die Staatsanwältin beurteilte die Kommission, die auch die Richterin beurteilt hatte.

\section{A.2 auch-self-paced-reading materials}

1. a. Das Marketingteam, das der Manager beraten hat, hatte auch der The $_{N / A}$ marketing-team $\mathrm{RP}_{N / A}$ the $N_{N}$ manager advised has, had also the ${ }_{N}$ Geschftsführer beraten. CEO advised.

'The marketing-team that the manager advised had also been advised by the CEO.' 
b. Das Marketingteam,/ das der Manager beraten hat,/ hatte vorher der the marketing-team $\mathrm{RP}_{N / A}$ the ${ }_{N}$ manager advised has had before the ${ }_{N}$ Geschäftsführer beraten.

CEO advised

'The marketing-team that the manager advised had previously been advised by the CEO.'

c. Das Marketingteam, das den Manager beraten hat, hatte auch der The $_{N / A}$ marketing-team $\mathrm{RP}_{N / A}$ the $A$ manager advised has, had also the ${ }_{N}$ Geschäftsführer beraten.

CEO advised.

'The marketing-team that advised the manager had also been advised by the CEO.'

d. Das Marketingteam, das den Manager beraten hat, hatte vorher der The $_{N / A}$ marketing-team $\mathrm{RP}_{N / A}$ the ${ }_{A}$ manager advised has, had before the ${ }_{N}$ Geschäftsführer beraten.

CEO advised.

'The marketing-team that advised the manager had previously been advised by the CEO.'

Question for all conditions:

Hatte das Marketingteam den Manager beraten?

Had the marketing-team advised the manager?

2. a. Die Spionin,/ die der Kommissar verfolgte,/+ hatte auch der KGB-Mann the spy RP the super-intendent chased had also the KGB-man verfolgt. chased

b. Die Spionin,/ die der Kommissar verfolgte,/+ hatte vorher der KGB-Mann verfolgt.

c. Die Spionin,/ die den Kommissar verfolgte,/+ hatte auch der KGB-Mann verfolgt.

d. Die Spionin,/ die den Kommissar verfolgte,/+ hatte vorher der KGB-Mann verfolgt.

Question for all conditions:

Wurde der Kommissar von der Spionin verfolgt?

Was the super-intendent chased by the spy?

3. a. Die Grenzbeamtin,/ die der Polizist kontrollierte,/+ hatte auch der the border-officer RP the police-officer examined had also the Staatsanwalt kontrolliert. prosecutro examined

b. Die Grenzbeamtin,/ die der Polizist kontrollierte,/+ hatte vorher der Staatsanwalt kontrolliert.

c. Die Grenzbeamtin,/ die den Polizisten kontrollierte, $/+$ hatte auch der Staatsanwalt kontrolliert.

d. Die Grenzbeamtin,/ die den Polizisten kontrollierte,/+ hatte vorher der Staatsanwalt kontrolliert.

Question for all conditions:

Hatte die Grenzbeamtin den Staatsanwalt kontrolliert?

Had the border officer examined the prosecutor? 
4. a. Die Cellistin,/ die der Komponist bewunderte,/+ hatte auch der Dirigent the cellist RP the composer admired had also the director bewundert. admired

b. Die Cellistin,/ die der Komponist bewunderte,/+ hatte zuvor der Dirigent bewundert.

c. Die Cellistin,/ die den Komponisten bewunderte,/+ hatte auch der Dirigent bewundert.

d. Die Cellistin,/ die den Komponisten bewunderte,/+ hatte zuvor der Dirigent bewundert.

Question for all conditions:

Wurde der Dirigent von der Cellistin bewundert?

Was the director admired by the cellist?

5. a. Die Gruppe,/ die der Naturschutzverein unterstützte,/+ hatte the group RP the nature-conversancy-orangisation supported had auch der Bürgermeister unterstützt. also the mayor supported

b. Die Gruppe,/ die der Naturschutzverein unterstützte,/+ hatte vorher der Bürgermeister unterstützt.

c. Die Gruppe,/ die den Naturschutzverein unterstützte,/+ hatte auch der Bürgermeister unterstützt.

d. Die Gruppe,/ die den Naturschutzverein unterstützte,/+ hatte vorher der Bürgermeister unterstützt.

Question for all conditions:

Hatte die Gruppe den Naturschutzverein unterstützt?

Had the group supported the nature conservancy organisation?

6. a. Die Norwegerin,/ die der Finne besiegte, $/+$ hatte auch der Schwede besiegt. the NorwegianFEM RP the Fin defeated had also the Swede defeated

b. Die Norwegerin,/ die der Finne besiegte,/+ hatte vorher der Schwede besiegt.

c. Die Norwegerin,/ die den Finnen besiegte,/+ hatte auch der Schwede besiegt.

d. Die Norwegerin,/ die den Finnen besiegte,/+ hatte vorher der Schwede besiegt. Question for all conditions:

Wurde der Finne von der Norwegerin besiegt?

Was the Fin defeated by the Norwegian?

7. a. Das kleine Mädchen,/ das der Erzieher ermutigte,/ hatte auch der the little girl RP the educator encouraged had also the Elternsprecher ermutigt. parent-representative encouraged

b. Das kleine Mädchen,/ der Erzieher ermutigte,/ hatte zuvor der Elternsprecher ermutigt.

c. Das kleine Mädchen,/ das den Erzieher ermutigte,/ hatte auch der Elternsprecher ermutigt. 
d. Das kleine Mädchen,/ das den Erzieher ermutigte,/ hatte zuvor der Elternsprecher ermutigt.

Question for all conditions:

Hatte der Elternsprecher das kleine Mädchen ermutigt?

Had the parent-representative encouraged the little girl?

8. a. Die Künstlerin,/ die der Tourist fotografierte,/ hatte auch der Journalist the artist RP the tourist photographed had also the journalist fotografiert. photographed

b. Die Künstlerin,/ die der Tourist fotografierte,/ hatte vorher der Journalist fotografiert.

c. Die Künstlerin,/ die den Touristen fotografierte,/ hatte auch der Journalist fotografiert.

d. Die Künstlerin,/ die den Touristen fotografierte,/ hatte vorher der Journalist fotografiert.

Question for all conditions:

Wurde die Künstlerin vom Journalisten fotografiert?

Was the artist photographed by the journalist?

9. a. Die Italienerin,/ die der Student unterrichtete,/+ hatte auch der Musiklehrer the Italian RP the student taught had also the music-teacher unterrichtet. taught

b. Die Italienerin,/ die der Student unterrichtete,/+ hatte zuvor der Musiklehrer unterrichtet.

c. Die Italienerin,/ die den Studenten unterrichtete,/+ hatte auch der Musiklehrer unterrichtet.

d. Die Italienerin,/ die den Studenten unterrichtete,/+ hatte zuvor der Musiklehrer unterrichtet.

Question for all conditions:

Hatte der Student die Italienerin unterrichtet?

Had the student taught the Italian?

10. a. Die Putzfrau,/ die der alte Herr suchte,/+ hatte auch der kleine Junge the cleaner RP the old man looked-for had also the little boy gesucht.

looked-for

b. Die Putzfrau,/ die der alte Herr suchte, $/+$ hatte vorher der kleine Junge gesucht.

c. Die Putzfrau,/ die den alten Herrn suchte,/+ hatte auch der kleine Junge gesucht.

d. Die Putzfrau,/ die den alten Herrn suchte,/+ hatte vorher der kleine Junge gesucht. Question for all conditions:

Wurde der alte Herr von der Putzfrau gesucht?

Was the old man looked for by the cleaner? 
11. a. Das Computergenie,/ das der Schachspieler beobachtete, $/+$ hatte auch der the computer-genius RP the chess-player watched had also the Programmierer beobachtet. programmer watched

b. Das Computergenie,/ das der Schachspieler beobachtete, /+ hatte vorher der Programmierer beobachtet.

c. Das Computergenie, / das den Schachspieler beobachtete, $/+$ hatte auch der Programmierer beobachtet.

d. Das Computergenie,/ das den Schachspieler beobachtete,/+ hatte vorher der Programmierer beobachtet.

Question for all conditions:

Hatte das Computergenie den Programmierer beobachtet?

Had the chess player watched the programmer?

12. a. Die Politikerin,/ die der Dichter erkannte,/+ hatte auch der Gastgeber the politician RP the poet recognised had also the host erkannt. recognised

b. Die Politikerin,/ die der Dichter erkannte,/+ hatte zuvor der Gastgeber erkannt.

c. Die Politikerin,/ die den Dichter erkannte,/+ hatte auch der Gastgeber erkannt.

d. Die Politikerin,/ die den Dichter erkannte,/+ hatte zuvor der Gastgeber erkannt. Question for all conditions:

Wurde der Gastgeber von der Politikerin erkannt?

Was the host recognised by the politician?

13. a. Die Tennisspielerin,/ die der Trainer nominierte,/ hatte auch der the tennis-player RP the trainer nominated had also the DTB-Vorsitzende nominiert. DTB-chairman nominated

b. Die Tennisspielerin,/ die der Trainer nominierte,/ hatte vorher der DTB-Vorsitzende nominiert.

c. Die Tennisspielerin,/ die den Trainer nominierte,/ hatte auch der DTB-Vorsitzende nominiert.

d. Die Tennisspielerin,/ die den Trainer nominierte,/ hatte vorher der DTB-Vorsitzende nominiert.

Question for all conditions:

Hatte der Trainer die Tennisspielerin nominiert?

Had the trainer nominated the tennis player?

14. a. Die Regisseurin,/ die der Schauspieler um Rat fragte, $/+$ hatte auch der the director RP the actor for advice asked had also the Intendant um Rat gefragt.

head-of-programming for advice asked

b. Die Regisseurin,/ die der Schauspieler um Rat fragte,/+ hatte vorher der Intendant um Rat gefragt.

c. Die Regisseurin,/ die den Schauspieler um Rat fragte,/+ hatte auch der Intendant um Rat gefragt. 
d. Die Regisseurin,/ die den Schauspieler um Rat fragte,/+ hatte vorher der Intendant um Rat gefragt.

Question for all conditions:

Wurde die Regisseurin vom Schauspieler um Rat gefragt?

Was the director asked for advice by the actor?

15. a. Die Sportreporterin,/ die der Athlet anrief,/+ hatte auch der Sponsor the sports-reporter RP the athlete called had also the sponsor angerufen.

called

b. Die Sportreporterin,/ die der Athlet anrief,/+ hatte vorher der Sponsor angerufen.

c. Die Sportreporterin,/ die den Athleten anrief,/+ hatte auch der Sponsor angerufen.

d. Die Sportreporterin,/ die den Athleten anrief,/+ hatte vorher der Sponsor angerufen. Question for all conditions:

Hatte der Sponsor die Sportreporterin angerufen?

Had the sponsor called the sports reporter?

16. a. Die Anwältin,/ die der Sekretär befragte,/+ hatte auch der Referendar the lawyer RP the secretary interrogated had also the clerk

befragt. interrogated

b. Die Anwältin,/ die der Sekretär befragte,/+ hatte vorher der Referendar befragt.

c. Die Anwältin,/ die den Sekretär befragte, $/+$ hatte auch der Referendar befragt.

d. Die Anwältin,/ die den Sekretär befragte,/+ hatte vorher der Referendar befragt. Question for all conditions:

Wurde der Referendar von der Anwïtin befragt?

Was the clerk interrogated by the lawyer?

17. a. Das Model,/ das der Fotograf kontaktierte,/+ hatte auch der Designer the model RP the photographer contacted had also the designer kontaktiert. contacted

b. Das Model,/ das der Fotograf kontaktierte,/+ hatte vorher der Designer kontaktiert.

c. Das Model,/ das den Fotografen kontaktierte,/+ hatte auch der Designer kontaktiert.

d. Das Model,/ das den Fotografen kontaktierte,/+ hatte vorher der Designer kontaktiert.

Question for all conditions:

Hatte das Model den Fotografen kontaktiert?

Had the model contacted the photographer?

18. a. Die Barmixerin,/ die der Koch anstellte,/+ hatte auch der Jazz-Club the bartender RP the cook hired had also the jazz-club angestellt. hired

b. Die Barmixerin,/ die der Koch anstellte,/+ hatte vorher der Jazz-Club angestellt. 
c. Die Barmixerin,/ die den Koch anstellte,/+ hatte auch der Jazz-Club angestellt.

d. Die Barmixerin,/ die den Koch anstellte,/+ hatte vorher der Jazz-Club angestellt. Question for all conditions:

Wurde der Koch von der Barmixerin angestellt?

Was the cook hired by the bartender?

19. a. Die Sängerin,/ die der Bühnenbildner empfahl,/+ hatte auch der the singer RP the stage-designer recommended had also the Musikdirektor empfohlen. music-director recommended

b. Die Sängerin,/ die der Bühnenbildner empfahl,/+ hatte vorher der Musikdirektor empfohlen.

c. Die Sängerin,/ die den Bühnenbildner empfahl,/+ hatte auch der Musikdirektor empfohlen.

d. Die Sängerin,/ die den Bühnenbildner empfahl,/+ hatte vorher der Musikdirektor empfohlen.

Question for all conditions:

Hatte der Musikdirektor die Sängerin empfohlen?

Had the music director recommended the singer?

20. a. Die Schönheitskönigin,/ die der Quizgewinner beglückwünschte,/+ hatte auch the beauty-queen RP the quiz-winner congratulated had also der Showmaster beglückwünscht. the host congratulated

b. Die Schönheitskönigin,/ die der Quizgewinner beglückwünschte,/+ hatte vorher der Showmaster beglückwünscht.

c. Die Schönheitskönigin,/ die den Quizgewinner beglückwünschte,/hatte auch der Showmaster beglückwünscht.

d. Die Schönheitskönigin,/ die den Quizgewinner beglückwünschte,/+ hatte vorher der Showmaster beglückwünscht.

Question for all conditions:

Wurde die Schönheitskönigin vom Showmaster beglückwünscht?

Was the beauty queen congratulated by the host?

21. a. Die Klientin,/ die der Makler überredete,/+ hatte auch der the client RP the real-estate-agent convinced had also the Hausmeister überredet. janitor convinced

b. Die Klientin,/ die der Makler überredete, / + hatte vorher der Hausmeister überredet.

c. Die Klientin,/ die den Makler überredete,/+ hatte auch der Hausmeister überredet.

d. Die Klientin,/ die den Makler überredete,/+ hatte vorher der Hausmeister überredet. Question for all conditions:

Hatte der Makler die Klientin überredet?

Had the real estate agent convinced the client? 
22. a. Das Aufsichtsratsmitglied,/ das der Grafiker überzeugte,/+ hatte auch der the board-member RP the graphic designer convinced had also Kreativdirektor überzeugt.

the art director convinced

b. Das Aufsichtsratsmitglied,/ das der Grafiker überzeugte,/+ hatte vorher der Kreativdirektor überzeugt.

c. Das Aufsichtsratsmitglied,/ das den Grafiker überzeugte,/+ hatte auch der Kreativdirektor überzeugt.

d. Das Aufsichtsratsmitglied,/ das den Grafiker überzeugte,/+ hatte vorher der Kreativdirektor überzeugt.

Question for all conditions:

Wurde das Aufsichtsratmitglied vom Grafiker überzeugt?

Was the boardmember convinced by the graphic designer?

23. a. Die Gastmoderatorin,/ die der Tenor ankündigte,/ hatte auch der the guest-host RP the tenor announced had also the Programmdirektor angekündigt. head-of-programming announced

b. Die Gastmoderatorin,/ die der Tenor ankündigte,/ hatte zuvor der Programmdirektor angekündigt.

c. Die Gastmoderatorin,/ die den Tenor ankündigte,/ hatte auch der Programmdirektor angekündigt.

d. Die Gastmoderatorin,/ die den Tenor ankündigte,/ hatte zuvor der Programmdirektor angekündigt.

Question for all conditions:

Hatte die Gastmoderatorin den Programmdirektor angekündigt?

Had the guest host announced the head of programming?

24. a. Die Kommission,/ die der Staatsanwalt beurteilte,/ hatte auch der Richter the commission RP the prosecutor assessed had also the judge beurteilt. assessed

b. Die Kommission, / die der Staatsanwalt beurteilte,/ hatte zuvor der Richter beurteilt.

c. Die Kommission,/ die den Staatsanwalt beurteilte,/ hatte auch der Richter beurteilt.

d. Die Kommission,/ die den Staatsanwalt beurteilte,/ hatte zuvor der Richter beurteilt. Question for all conditions:

Wurde die Kommission von dem Richter beurteilt?

Was the commission assessed by the judge?

\section{References}

Abusch, D.: 2005, Triggering from alternative sets and projection of pragmatic presuppositions. 
Bader, M. and Meng, M.: 1999, Subject-object ambiguities in german embedded clauses: An across-the-board comparison, Journal of Psycholinguistic Research 28(2), 121-143.

Beaver, D.: 1997, Presupposition, in J. van Benthem and A. ter Meulen (eds), The Handbook of Logic and Language, Elsevier, Amsterdam, pp. 9391008.

Beaver, D. and Krahmer, E.: 2001, Presupposition and partiality: Back to the future, Journal of Logic, Language and Information 10(2), 147-182.

Beaver, D. and Zeevat, H.: to appear, Accommodation, in G. Ramchand and C. Reiss (eds), Oxford Handbook of Linguistic Interfaces, Oxford University Press.

beim Graben, P., Saddy, J. D., Schlesewsky, M. and Kurths, J.: 2000, Symbolic dynamics o fevent-related brain potentials, Physical Review 62, 5518-5541.

Chambers, C. and Juan, V. S.: 2005, Accommodation and the interpretation of presupposition during referential processing. Poster presented at the 18th CUNY Sentence Processing Conference.

Christianson, K., Hollingworth, A., Halliwell, J. F. and Ferreira, F.: 2001, Thematic-roles assigned along the garden path linger, Cognitive Psychology 42, 368-407.

Crain, S. and Steedman, M.: 1985, On not being led up the garden path. the use of context by the psychological parser, in D. R. Dowty, L. Karttunen and A. Zwicky (eds), Natural Language Parsing: Psychological, Computational, and Theoretical Perspectives, Cambridge University Press, Cambridge, pp. 320-358.

Geurts, B.: 1999, Presuppositions and pronouns, Elsevier, Amsterdam ; New York. 99054254 Bart Geurts. Includes bibliographical references (p. [223]-229) and indexes.

Heim, I.: 1982, The semantics of definite and indefinite noun phrases, $\mathrm{PhD}$ thesis, University of Massachusetts.

Heim, I.: 1983a, File change semantics and the familiarity theory of definiteness, in R. Baeuerle, R. Schwarze and A. von Stechow (eds), Meaning, Use, and Interpretation of Language, De Gruyter, Berlin, pp. 164-189. 
Heim, I.: 1983b, On the projection problem for presuppositions, in M. Barlow, D. Flickinger and M. Wescoat (eds), WCCFL 2, pp. 114-125.

Heim, I.: 1992, Presupposition projection and the semantics of attitude verbs, Journal of Semantics 9, 183-221.

Hemforth, B.: 1993, Kognitives Parsing: Repräsentation und Verarbeitung grammatischen Wissens, Infix, Sankt Augustin.

Kamp, H.: 1981, A theory of truth and semantic representation, in J. Groenendijk, T. Janssen and M. Stokhof (eds), Formal Methods in the Study of Language: Proceedings of the Third Amsterdam Colloquium, Vol. I, Mathematical Center, Amsterdam, pp. 227-321.

Kamp, H. and Reyle, U.: 1993, From Discourse to Logic, Kluwer, Dordrecht.

Karttunen, L.: 1973, Presuppositions of compound sentences, Linguistic Inquiry 4(2), 169-193.

Karttunen, L.: 1974, Presupposition and linguistic context, Theoretical Linguistics 1, 181-194.

Kim, A. and Osterhout, L.: 2005, The independence of combinatory semantic processing: Evidence from event-related potentials, Journal of Memory and Language 52, 205-225.

Krifka, M.: 1999, Additive particles under stress, SALT, CLC Publications, pp. 111-128.

Kripke, S.: 1991, Presupposition and anaphora: Remarks on the formulation of the projection problem.

Lewis, D.: 1979, Scorekeeping in a language game., in R. Baeuerle, U. Egli and A. von Stechow (eds), Semantics from Different Points of View, Vol. 172-187, Springer, Berlin.

Noveck, I. and Sperber, D. (eds): 2004, Experimental Pragmatics, Palgrave Macmillan.

Schlesewsky, M., Fanselow, G., Kliegl, R. and Krems, J.: 2000, The subjectpreference in the processing of locally ambiguous wh-questions in german, in B. Hemforth and L. Konieczny (eds), German sentence processing, Kluwer, Dordrecht, pp. 65-93. 
Schlesewsky, M. and Friederici, A.: 2003, Sentence processing mechanisms, in L. Nadel (ed.), Encyclopedia of cognitive science, Macmillan Reference, London, pp. 1149-1155.

Simons, M.: 2001, On the conversational basis of some presuppositions, in R. Hastings, B. Jackson and Z. Zvolensky (eds), SALT 11, CLC Publications.

Spenader, J.: 2002, Presuppositions in Spoken Discourse, PhD thesis, University of Stockholm. Computational Linguistics.

Stalnaker, R.: 1973, Presuppositions, Journal of Philosophical Logic 2, 447457.

Stalnaker, R.: 1974, Pragmatic presuppositions, in M. Munitz and P. Unger (eds), Semantics and Philosophy, New York University Press, New York, pp. 197-214.

van Berkum, J. J. A., Brown, C. M. and Hagoort, P.: 1999, Early referential context effects in sentence processing: Evidence from event-related brain potentials, Journal of Memory and Language 41, 147-182.

van Berkum, J. J. A., Brown, C. M., Hagoort, P. and Zwitserlood, P.: 2003, Event-related brain potentials reflect discourse-referential ambiguity in spoken language comprehension, Psychophysiology 40, 235-248.

van der Sandt, R. A.: 1992, Presupposition projection as anaphora resolution, Journal of Semantics 9(4), 333-377.

van der Sandt, R. and Geurts, B.: 2001, Too, 13th Amsterdam Colloquium.

van Rooy, R.: 1999, Against local accommodation, in M. K. Bart Geurts and R. van der Sandt (eds), Focus and Presupposition in Multi-speaker Discourse. Workshop held at the 11th European Summer School in Logic, Language, and Information, ESSLI, Amsterdam.

von Fintel, K.: 2004, Would you believe it? the king of france is back! (presuppositions and truth-value intuitions), in M. Reimer and A. Bezuidenhout (eds), Descriptions and Beyond, Oxford University Press, Oxford, pp. 315-341. 